\title{
Rising Interest Rates, the Deficit, and Public Debt
}

\author{
Miguel Faria-e-Castro, Economist
}

A s the U.S. economy continues its second-longest expansion since World War II, with low unemployment and personal consumption expenditures inflation only slightly below its target, the Federal Reserve System has been gradually raising its target policy rate. Figure 1 shows that these interest rate increases come at a time when federal debt is at historically high levels, a fact that has raised concern. ${ }^{1}$ This essay investigates the projected impact of rising interest payments on the federal deficit and debt.

\section{A Simple Model of the Government Budget Constraint}

To assess the effects of future interest rate increases on public debt, I follow a simple model of the flow budget constraint for the federal government that highlights some of the channels through which interest rates can affect debt and the deficit:

New Debt $t_{t}-$ Maturing Debt $_{t}=$ Primary Deficit $t_{t}+$ Interest Payments $_{t}$.

The equation states that, in every period, the government must issue new debt to cover the primary deficit (the difference between non-interest spending and revenues), the principal on maturing debt, and interest payments on past debt. The primary deficit also contains transfers from the Federal Reserve to the Treasury, which can be particularly sensitive to changes in interest rates. ${ }^{2}$

I am interested in analyzing the prospective paths of the deficit and marketable federal debt as percentages of gross domestic product (GDP). Thus, I need projections of the paths of output growth, inflation, the federal funds rate, and the primary deficit until 2028. I obtain paths for output growth, inflation, and the federal funds rate from the Summary of Economic Projections published after every Federal Open Market Committee meeting. ${ }^{3}$ The projected path for the primary deficit is taken from the Congressional Budget Office's calculations. ${ }^{4}$

I consider the following three base scenarios: (1) "Low" is a situation where output growth, inflation, and the federal funds rate are at the lower end of their projected ranges.

(2) "High" is the converse scenario, where output growth, inflation, and the federal funds rate are at the higher end of their projected ranges. And (3) "Median" is the scenario

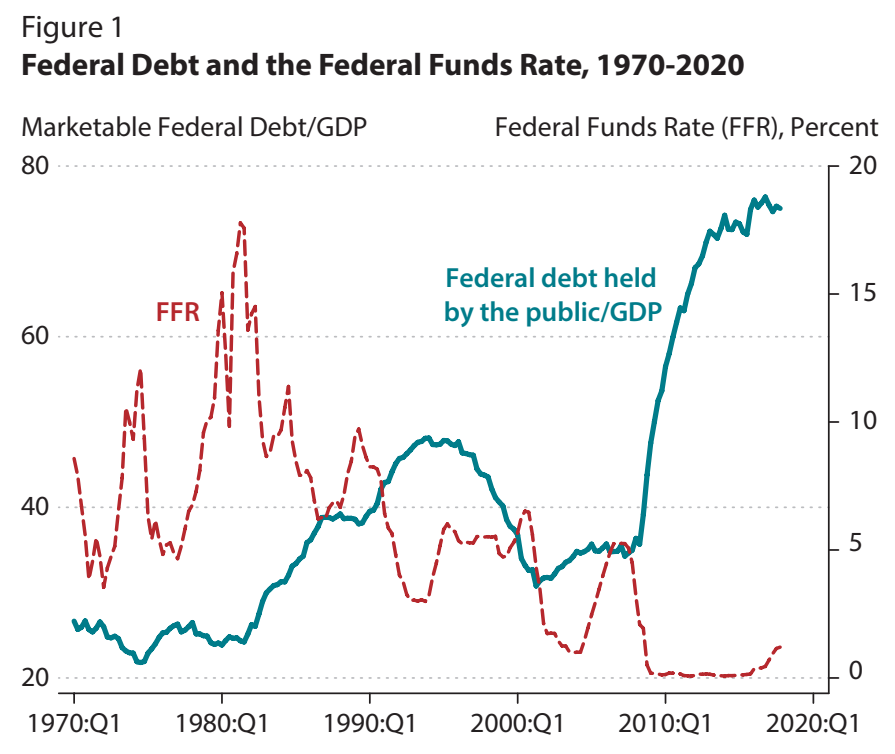

SOURCE: FRED ${ }^{\oplus}$, Federal Reserve Bank of St. Louis.

in which all these variables are at their median projected values. In all scenarios, I assume that the Federal Reserve responds to inflation by raising or lowering interest rates appropriately.

\section{Primary deficits matter more than rising interest rates for public debt.}

The final input is the maturity structure of public debt. ${ }^{5}$ The Fed directly controls only short-term interest rates, but the government borrows at many different maturities. This means that I also need a simple model of the yield curve, which governs how interest rates at different horizons depend on the federal funds rate and other macroeconomic factors. ${ }^{6}$ Furthermore, Fed transfers to the Treasury will also be affected by interest rates. These transfers are likely to fall as interest rates rise because the Fed must pay more interest on excess reserves. Finally, I assume that the Treasury keeps the maturity structure of federal debt constant. 
Figure 2

Projections for the Federal Deficit and Debt Held by the Public as Percentages of GDP, 2018-28

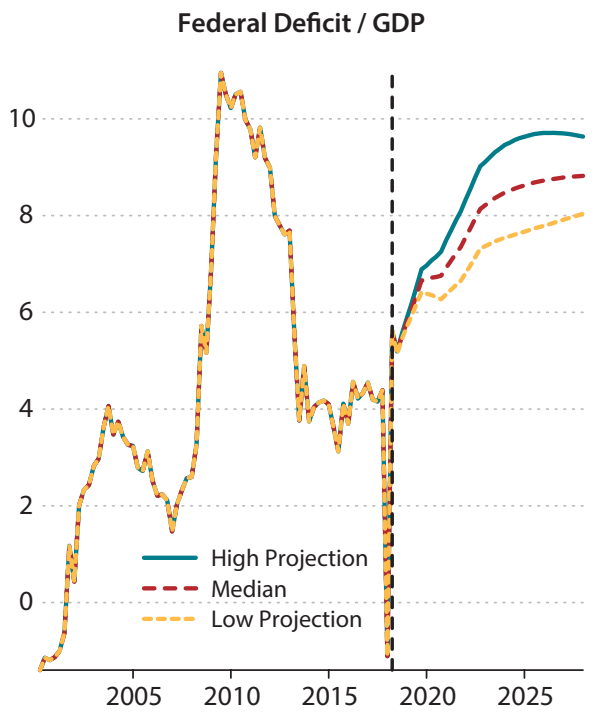
Debt Held by the Public/GDP

NOTE: FFR, federal funds rate.

SOURCE: Author's calculations. The sharp drop in the deficit in 2017:Q4 is due to a one-time tax on foreign corporate earnings. ${ }^{7}$

\section{Results and Projections}

Figure 2 plots the historical values as well as projected paths of the federal deficit and debt held by the public as percentages of GDP. Interest payments are likely to double in the next 10 years due to higher interest rates and higher federal debt. This creates upward pressure on federal deficits, which are also likely to be higher and may range from 7 to 10 percent of GDP, depending on the projected inputs. Figure 2 shows that, while debt is projected to increase to about 100 percent of GDP by 2028 , it does not seem to be extremely sensitive to the paths of output, inflation, and interest rates.

The most important factor is the obvious one: growing primary deficits. Figure 2 also compares the baseline "median" scenario to a scenario in which the primary deficit remains constant at 2018:Q1 levels. It shows that curbing primary deficits can significantly decelerate the growth of public debt and keep its value at less than 90 percent of GDP for the next 10 years. Keeping interest rates constant does not seem to achieve much, and it generates debt levels similar to those in the baseline median scenario.

\section{Conclusion}

In summary, rising interest rates are not a primary cause for the growing public debt. Rather, primary deficits seem to be the main driver of increasing debt levels.

\section{Notes}

1 See, for example, https://www.cnbc.com/2018/03/05/rising-interest-rateswill-be-devastating-to-the-us-economy-for-one-big-reason.html.

2 See this blog post for a more detailed discussion: https://www.stlouisfed.org/on-the-economy/2018/september/fed-payments-treasury-rising-interest-rates.

${ }^{3}$ Available on the Board of Governors of the Federal Reserve System website: https://www.federalreserve.gov/monetarypolicy/fomccalendars.htm.

4 See this blog post on the outlook for the federal budget: https://www.stlouisfed.org/on-the-economy/2017/october/outlook-federal-budget.

${ }^{5}$ A detailed description of the maturity structure of marketable debt used as an input can be found in this Regional Economist article: https://www.stlouisfed.org/publications/regional-economist/third-quarter-2018/rising-rates-borrowing-government.

6 The specification for the yield curve also includes some nonlinear terms to account for the fact that the term premium can vary with the level of interest rates.

7 See this FRED ${ }^{\circledast}$ Blog post for an explanation: https://fredblog.stlouisfed.org/2018/04/did-the-u-s-government-justachieve-a-surplus/. 